\title{
Removal of Cesium on Polyaniline Titanotungstate as Composite Ion Exchanger
}

\author{
I. M. El-Naggar ${ }^{1}$, E. S. Zakaria ${ }^{1}$, I. M. Ali ${ }^{1}$, Magdy Khalil ${ }^{1 *}$, M. F. El-Shahat ${ }^{2}$ \\ ${ }^{1}$ Atomic Energy Authority, Hot Labs. Center, Cairo, Egypt \\ ${ }^{2}$ Chemistry Department, Faculty of Science, Ain Shams University, Cairo, Egypt \\ Email: ${ }^{*}$ magdykhali17@yahoo.com
}

Received October 31, 2011; revised December 4, 2011; accepted December 12, 2011

\begin{abstract}
Polyaniline titanotungstate (PATiW) was synthesized by the sol-gel method. Adsorption isotherm studies of $\mathrm{Cs}^{+}$from aqueous solution are described. Elemental Composition, chemical solubility, ion-exchange capacity (IEC) and $\mathrm{pH}$ titration are studied. Distribution coefficients $\left(K_{d}\right)$ for ten metal ions have been determined. It was found that the polyaniline titanotungstate has high affinity and high selectivity for $\mathrm{Cs}^{+}$. The material was high separation of $\mathrm{Cs}^{+}$from other metal ions. The adsorbent capacity was determined using the Freundlich and Langmuir adsorption isotherm models. The $\mathrm{Cs}^{+}$ adsorption isotherm data fit best to the Freundlich isotherm model. The maximum $\mathrm{Cs}^{+}$uptake of polyaniline titanotungstate was found $217 \mathrm{mg} / \mathrm{g}$. A column tests were performed to determine the breakthrough curves with varying bed depths and flow rates in different solutions. The results show that the half breakthrough time increases proportionally with increasing bed depths. Kinetic studies for removal cesium from milk were investigated.
\end{abstract}

Keywords: Synthesis; Separation; Polyaniline Titanotungstate; Cesium

\section{Introduction}

Radioactive waste is an inevitable residue from the use of radioactive materials in industry, research and medicine, as well as from the use of nuclear power to generate electricity. The management and disposal of such waste is, therefore, an issue relevant to almost all countries. The ever increasing pressure to reduce the release of radioactive and other toxic substances into the environment requires constant improvement/upgrading of processes and technologies for treatment and conditioning of liquid radioactive waste. Treatment of liquid radioactive waste quite often involves the application of several steps such as filtration, precipitation, sorption, ion exchange, evaporation and/or membrane separation to meet the requirements both for the release of decontaminated effluents into the environment and the conditioning of waste concentrates for disposal. New materials and processes are under consideration and development in various countries [1]. Most of the combined radioactivity in liquid nuclearwaste is a result of the fission products ${ }^{137} \mathrm{Cs}$ and ${ }^{90} \mathrm{Sr} .{ }^{137} \mathrm{Cs}$ is an important radiocontaminant with its long half life ( $t_{1 / 2}=30.17$ years) and represents a serious radiological hazard because as an alkaline element, it is easily assimilable by living organisms [2]. The ion exchange is the most important method for the selective

${ }^{*}$ Corresponding author. adsorption and safe storage of ${ }^{137} \mathrm{Cs}$. Although a number of organic exchangers exist, which are selective towards cesium, they are easily decomposed when exposed to highly ionizing radiation. Inorganic ion exchangers have several superior qualities required for the treatment of nuclear waste effluents compared to organic resins. In order to obtain a combination of these advantages associated with polymeric and inorganic materials as ionexchangers, attempts have been made to develop polymeric-inorganic composite ion-exchangers by incorporation of organic monomers in the inorganic matrix [3]. Few such excellent ion-exchange materials have been developed in our laboratory and successfully being used in chromatographic techniques [4-6]. An inorganic precipitate ion-exchanger based on organic polymeric matrix must be an interesting material, as it should possess the mechanical stability due to the presence of organic polymeric species and the basic characteristics of an inorganic ion-exchanger regarding its selectivity for some particular metal ions [7-10]. It was therefore considered to synthesize such hybrid ion-exchangers with a good ion-exchange capacity, high stability, reproducibility and selectivity for metal ions, indicating its useful environmental application.

Efforts have been made to improve the chemical, thermal and mechanical stabilities of ion exchangers and to make them highly selective for certain metal ions. Sil- 
ica potassium cobalt hexacyanoferrate composite ion exchanger has excellent exchange properties of cesium [11]. Polyaniline Ce(IV) molybdate has high selectivity to $\mathrm{Cd}(\mathrm{II})$ [12]. Poly-o-methoxyaniline $\mathrm{Zr}(\mathrm{IV})$ molybdate has high selectivity to $\mathrm{Cd}(\mathrm{II})$ [13]. Acrylonitrile stannic(IV) tungstate has high selectivity to $\mathrm{Pb}(\mathrm{II})$ [14]. Cobalt ferrocyanide impregnated organic anion exchanger was found to be highly selective for cesium [15].

In the following parts of this contribution, composite absorbers, titanotungstate with polyaniline binding matrix was prepared and its properties and technological application are evaluated. Ion exchange capacity and distribution coefficient were determined towards cesium. Isotherm and column studies were applied at different conditions for removal cesium. It is found high selectivity for cesium from other metal ions from radioactive waste, aqueous solution and applied for removal cesium from milk.

\section{Experimental}

\subsection{Chemicals and Reagents}

All chemicals and reagents used in this work were of analytical grade purity and used without further purification. Cesium chloride, titanium tetrachloride, $\mathrm{TiCl}_{4} \cdot \mathrm{H}_{2} \mathrm{O}$, potassium persulphate $\left(\mathrm{K}_{2} \mathrm{~S}_{2} \mathrm{O}_{8}\right)$ were obtained from Prolabo (England). Sodium tungstate $\mathrm{Na}_{2} \mathrm{WO}_{2} \cdot 2 \mathrm{H}_{2} \mathrm{O}$, aniline $\left(\mathrm{C}_{6} \mathrm{H}_{5} \mathrm{NH}_{2}\right)$, nitric acid and hydrochloric acid were purchased from Adwic (Egypt).

All samples and chemicals used in this work were weighted using an analytical balance of Bosch type having maximum sensitivity of $10^{5} \mathrm{~g}$ and accuracy $\pm 0.001 / \mathrm{y}$. For the equilibrium experiments, a good mixing for the two phases was achieved using thermostatic shaker water bath of the type Julabo SW-20C obtained from West Germany.

\subsection{Preparation of Polyaniline Titanotungstate (PATiW)}

Polyaniline gels were prepared by mixing aqua volumes of the solutions of $10 \%$ aniline $\left(\mathrm{C}_{6} \mathrm{H}_{5} \mathrm{NH}_{2}\right)$ and $0.1 \mathrm{M}$ potassium persulphate with continuous stirring by a magnetic stirrer. Green colored polyaniline gels were obtained by keeping the solutions below $10^{\circ} \mathrm{C}$ for half an hour [16]. A precipitate of titanium tungstate was prepared at $\left(65^{\circ} \mathrm{C} \pm 1^{\circ} \mathrm{C}\right)$ by adding $1 \mathrm{M}$ titanium chloride solution to an aqueous solution of $1 \mathrm{M}$ sodium tungstate $\left(\mathrm{Na}_{2} \mathrm{WO}_{2} \cdot 2 \mathrm{H}_{2} \mathrm{O}\right)$ in equal volume ratio. The white precipitates were obtained, when the $\mathrm{pH}$ of the mixtures was adjusted to 6.5 by adding aqueous ammonia with constant stirring. The gels of polyaniline were added to the white inorganic precipitate of titanium and mixed thoroughly with constant stirring. The resultant green colored gels were kept for $24 \mathrm{~h}$ at room temperature $\left(25^{\circ} \mathrm{C} \pm 1{ }^{\circ} \mathrm{C}\right)$ for digestion. The supernatant liquid was decanted and the gel was rewashed with bidistilled water in order to remove fine adherent particles and was filtered by center fission. The excess acid was removed by washing with DMW and the material was dried in an air oven at $50^{\circ} \mathrm{C}$. The dried products were immersed in DMW to obtain small granules. They were converted to $\mathrm{H}$-form by treating with $0.01 \mathrm{M} \mathrm{HNO}_{3}$ for $24 \mathrm{~h}$ with occasional shaking intermittently replacing the supernatant liquid with fresh acid. The excess acid was removed after several washings with DMW and then dried at $50^{\circ} \mathrm{C}$. Several particles size of materials were obtained by sieving and kept in desiccators [16].

\subsection{Instrumentation}

The applied adsorbents were thermally characterized by DTA-60 Shimadzu. and by FTIR analysis using BOMEM FTIR model MB 147, Canada. An elemental analyzer using atomic absorption spectrophotometer, AA6701F, Shimadzu. All samples and chemicals used in this work were weighted using an analytical balance of Bosch type having maximum sensitivity of $10^{5} \mathrm{~g}$ and accuracy $\pm 0.001 / \mathrm{y}$. For the equilibrium experiments, a good mixing for the two phases was achieved using thermostatic shaker water bath of the type Julabo SW-20C, west Germany. All the $\mathrm{pH}$ values of different solutions were measured using an Orion digital $\mathrm{pH}$ meter research model $610 \mathrm{~A}$ with microprocessor and have accuracy of \pm 0.02 units.

\subsection{Elemental Composition}

To determine the elemental composition of PATiW, the material was analyzed for $\mathrm{Ti}$ and $\mathrm{W}$ by X-ray fluorescence. Carbon, hydrogen and nitrogen contents of the material were determined by elemental analysis.

\subsection{Chemical Solubility}

The chemical solubility also plays an important role in the elucidation of properties of the ion-exchangers. Portions of $50 \mathrm{mg}$ of composite and inorganic titanotungstate in the $\mathrm{H}^{+}$form were treated with $50 \mathrm{ml}$ of varying concentration of acids, $\mathrm{NaOH}$, and also in distilled water for 3 weeks with occasional shaking.

\subsection{Ion-Exchange Capacity (IEC)}

The IEC of polyaniline was determined by the repeated batch technique, by equilibrating $50 \mathrm{mg}$ solid with $5 \mathrm{ml}$ of $0.1 \mathrm{M}$ cesium chloride solution on a shaker thermostat adjusted at $25^{\circ} \mathrm{C} \pm 1{ }^{\circ} \mathrm{C}$ and attain for equilibrium, then decontamination of solution was took place and saturation process was repeated until no further sorption. The solution was analyzed using atomic absorption in order 
to determine the amount of $\mathrm{Cs}^{+}$sorbet. The sorption (P) was calculated from the expressions:

$$
P=\left(\frac{C_{0}-C_{t}}{C_{0}}\right) \times 100
$$

where $C_{0}$ is the initial concentration $(\mathrm{mg} / \mathrm{L})$ and $C_{t}$ is the concentration at time $\mathrm{t}(\mathrm{mg} / \mathrm{L})$ of metal ion in solution, $V$ the volume (L) and $\mathrm{m}$ is the weight $(\mathrm{g})$ of the adsorbent.

The sorption capacity was calculated using the following equation:

$$
\text { capacity }=\frac{\% \text { uptake }}{100} \times C_{0} \times V \times Z \text { meq } \cdot \mathrm{g}^{-1}
$$

where, $C_{0}$ is the initial concentration of solution, $Z$ is the charge of adsorbed metal ion, $V$ is the solution volume $(\mathrm{ml})$, and $m$ is the weight of the exchanger $(\mathrm{g})$.

\section{7. pH Titration}

The Topp and Pepper method [17] was employed for $\mathrm{pH}$ titration studies of PATiW in solutions of alkali metal chlorides and their hydroxides. $200 \mathrm{mg}$ was placed in a column that was fitted with glass wool at its bottom. A glass bottle containing $20 \mathrm{~mL}$ of $0.001 \mathrm{M} \mathrm{HCl}$ was placed below the column, and for determination of $\mathrm{pH}$, a glass electrode was placed in the solution, then $75 \mathrm{~mL}$ of $0.1 \mathrm{M}$ of $\mathrm{NaOH}$ was poured into the column. Titration was carried out, by passing the $\mathrm{NaOH}$ solution at a drop rate of about $1 \mathrm{~mL} / \mathrm{min}$. The $\mathrm{pH}$ of the solution was recorded until equilibrium was attained.

\subsection{Distribution Studies}

The distribution behavior of metal ions plays an important role in the determination of the material's selectivity. In certain practical applications, equilibrium is most conveniently expressed in terms of the distribution coefficients of the counter ions. The distribution coefficients $\left(K_{d}\right)$ for different metal ions $\left(\mathrm{Cs}^{+}, \mathrm{Va}^{5+}, \mathrm{Cr}^{3+}, \mathrm{Zr}^{4+}, \mathrm{As}^{5+}\right.$, $\mathrm{Mo}^{6+}, \mathrm{Co}^{2+}, \mathrm{Zn}^{2+}, \mathrm{Cu}^{2+}$ and $\mathrm{Cd}^{2+}$ ) were determined by batch method as a function of $\mathrm{pH}$. The $K_{d}$ values of $\mathrm{Cs}^{+}$ were determined by shaking $20 \mathrm{mg}$ of each PATiW in $\mathrm{H}^{+}$ form with $10 \mathrm{~mL}$ of $\mathrm{HNO}_{3}$ solutions containing $10^{-4}$ $\mathrm{mol} \cdot \mathrm{L}^{-1}$ cesium ion solutions as chloride, where $K_{d}$ values of other metal ions were determined by shaking 50 mg samples of PATiW in $\mathrm{H}^{+}$form with $5 \mathrm{~mL}$ of $\mathrm{HNO}_{3}$ solutions containing $10^{-5} \mathrm{~mol} \cdot \mathrm{L}^{-1}$ metal ions as chloride in order to rise the sorption of this ions. After $24 \mathrm{~h}$ with intermittent shaking or continuous shaking for $6 \mathrm{~h}$ in a shaker at $25^{\circ} \mathrm{C} \pm 1^{\circ} \mathrm{C}$ to attain equilibrium. The solutions were then filtered and metal ions were determined using AAS or ICP. The $K_{d}$ values were calculated by the following equation;

$$
K_{d}=\frac{(I-F)}{F} \frac{V}{m}\left(\mathrm{~mL} \cdot \mathrm{g}^{-1}\right)
$$

where $I$ is the initial amount of metal ion in the aqueous phase $\left(\mathrm{mg} \cdot \mathrm{L}^{-1}\right), \mathrm{F}$ is the final amount of metal ion in the aqueous phase $\left(\mathrm{mg} \cdot \mathrm{L}^{-1}\right), \mathrm{V}$ is the volume of the initial solution in $\mathrm{ml}$ and $\mathrm{m}$ is the dry mass of the ion exchanger in $g$.

\subsection{Separation Factor}

For the preferential uptake of the metal ion, the separation factor is determined in the separation of two metal ions. Separation factor $\alpha_{B}^{A}$ can be calculated as:

$$
\alpha_{B}^{A}=\frac{K_{d}(A)}{K_{d}(B)}
$$

where $K_{d}(A)$ and $K_{d}(B)$ are the distribution coefficient for the two competing species $A$ and $B$ in the ion-exchange system.

\subsection{Sorption Isotherm}

Batch adsorption studies of cesium ions was performed at different temperatures and neutral $\mathrm{pH}$ to obtain the equilibrium isotherms. A series of experiments were carried out by contacting a fixed amount of adsorbent $50 \mathrm{mg}$ with $2.5 \mathrm{~mL}$ of $\mathrm{Cs}$ ion solution and have varying concentrations cover the range of 13 to $13290 \mathrm{mg} \cdot \mathrm{L}^{-1}$ and agitated for a sufficiently time $(\sim 24 \mathrm{~h})$ required to reach equilibrium. Then, adsorbent was decantation and the amount of metal ion retained in the adsorbent, $q$, was calculated using:

$$
q=\left(c_{0}-c_{e}\right) \frac{V}{m}
$$

where $C_{0}$ and $C_{e}$ are the initial and equilibrium concentration of $\mathrm{Cs}$ in aqueous solution.

\subsection{Column Operation}

A glass column of $1 \mathrm{~cm}$ diameter was used in this study. The column was packed of a fixed amount the composite and washed with distilled water and then all column studies were performed. The breakthrough curves $\left(\mathrm{C} / \mathrm{C}_{0}\right.$ vs. volume) obtained for $\mathrm{Cs}^{+}$sorption onto PATiW at different bed depths 3.0 and $4.0 \mathrm{~cm}$ of $2.5 \mathrm{~mL} \cdot \mathrm{min}^{-1}$ flow rate and at $140 \mathrm{mg} \cdot \mathrm{L}^{-1}$ of aqueous cesium solution. Also the breakthrough curves were carried out from acidic simulant $\left(0.5 \mathrm{M} \mathrm{HNO}_{3}+0.1 \mathrm{M} \mathrm{NaNO}_{3}\right)$ and alkaline simulant $\left(0.5 \mathrm{M} \mathrm{NaOH}+0.1 \mathrm{M} \mathrm{NaNO}_{3}\right)$ solutions. The concentration of cesium in the feed solution was fixed at $13 \mathrm{mg} \cdot \mathrm{L}^{-1}$ with $0.7 \mathrm{ml} \cdot \mathrm{min}^{-1}$ flow rate and bed depth 1.0 $\mathrm{cm}$.

The break-through percentage was calculated as 


$$
\text { Breakthrough }=\frac{C}{C_{0}}
$$

where $C$ and $C_{0}$ are the concentrations of cesium in the effluent and feed solution respectively.

The sorption capacity $(q)$ of the PATiW was calculated by

$$
q=\frac{V_{50} \times C_{0}}{W} \mathrm{~mL} \cdot \mathrm{g}^{-1}
$$

where $V_{50}$ is the effluent volume corresponding to $50 \%$ breakthrough, $C_{0}$ is the concentration of cesium in the feed solution $\left(\mathrm{mg} \cdot \mathrm{g}^{-1}\right)$ and $W$ is the mass of composite absorber (g).

\subsection{Recover Cesium from Milk}

Milk with 3\%-fat solution was prepared with $10^{-2} \mathrm{M}$ of cesium, this solution labeled with ${ }^{134} \mathrm{Cs}$ active. Kinetic studies are carried with added $5 \mathrm{ml}$ of milk solution to 50 mg of PATiW and shaking in thermostated shaker water bath at $25^{\circ} \mathrm{C}$, at interval time stopped shaker and withdrawn $1 \mathrm{ml}$ of milk solution for counting using a scintillation detector head $(\mathrm{NaI})$ connected to scalar of the type SR-7 obtained by Nuclear Enterprises, USA and/or by Multichannel Analyzer Genie-200, spectroscopy system CANBERRA Industries INC (USA) allowed to equilibrate at room temperature. The Cs $\gamma$-ray activity in the tested milk was larger than background by at least 3 times.

\section{Results and Discussion}

Titanium tungstate was found to be high stable, but have poor capacity for metal ions [18]. In an attempt to obtain materials with improved ion exchange properties and selective ion exchangers for the treatment of nuclear waste. So, PATiW has been synthesized by using this advanced class of inorganic ion-exchanger, which provided high selective andseparation for ${ }^{134} \mathrm{Cs}$ from metal ions. It was also noticed that the $\mathrm{Cs}^{+}$ion-exchange capacity of the composite material $\left(1.82 \mathrm{meq} \cdot \mathrm{g}^{-1}\right)$ [16].

Polyaniline can be easily synthesized chemically from acidic aqueous solutions. In this study, polyaniline gel was prepared by oxidative coupling using $\mathrm{K}_{2} \mathrm{~S}_{2} \mathrm{O}_{8}$ in an acidic aqueous medium at below $10^{\circ} \mathrm{C}$ as given below [19]:

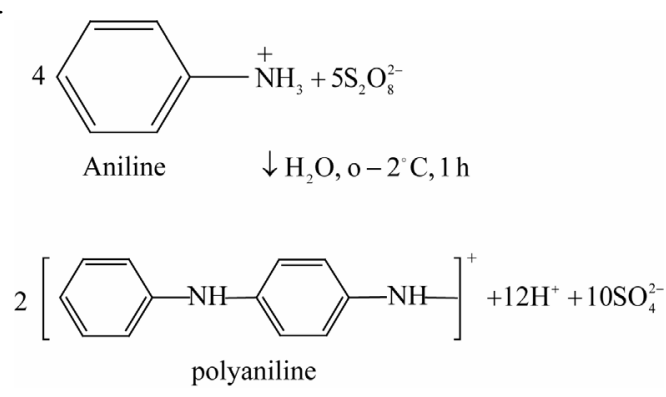

The effect of temperature on the reaction seems to be very pronounced. Aniline underwent oxidative coupling only below $10^{\circ} \mathrm{C}$ very effectively, leading to a good quantity of polyaniline with fairly good yield. The binding of polyaniline into the matrix of titanotungstate can be considered as:
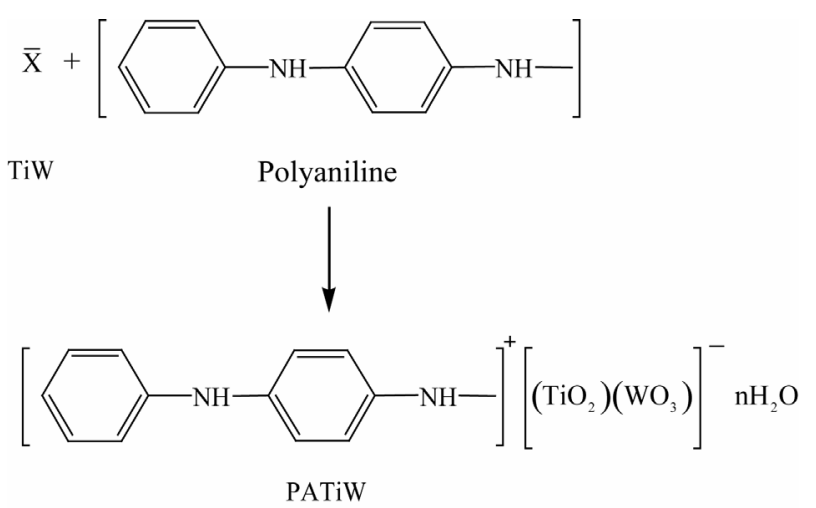

The formation of inorganic precipitate $\mathrm{TiW}\left(\mathrm{X}^{-}\right)$was significantly affected by the $\mathrm{pH}$ of the mixture, and the most favorable $\mathrm{pH}$ of the mixture was 6.5. The preparation of the inorganic precipitate at $\mathrm{pH}$ lower or higher than 6.5 lead to decrease in yield and in ion-exchange capacity of the material.

The weight percent composition of the material was found to be Ti, $15.15 \%$; W, 44.6\%; C, 19.1\%; H, 2.3\%; $\mathrm{N}, 3.7 \%$; and $\mathrm{O}, 15.0 \%$. The corresponding molar ratio of $\mathrm{Ti}, \mathrm{W}, \mathrm{C}, \mathrm{H}, \mathrm{N}$, and $\mathrm{O}$ in the material was estimated as 1.34:1.0:6.19:9.1:1.015:3.6, which can suggest the following formula of the material:

$$
\left[\left(\mathrm{TiO}_{2}\right)\left(\mathrm{WO}_{3}\right)\left(-\mathrm{C}_{6} \mathrm{H}_{4} \mathrm{NH}-\right)\right] \cdot n \mathrm{H}_{2} \mathrm{O} \text {. }
$$

Assuming that only the external water molecules $(n)$ are lost at $130^{\circ} \mathrm{C}$, the $10 \%$ weight loss of mass represented by TGA curve must be due to the loss of $n \mathrm{H}_{2} \mathrm{O}$ from the above structure. The value of $(n)$ can be calculated using Alberti's equation:

$$
18 n=X(M+18 n) / 100
$$

where $X$ is the percent weight loss $(10 \%)$ of the exchanger by heating up to $130^{\circ} \mathrm{C}$ and $(M+18 n)$ is the molecular weight of the material. The calculations indicated that $\sim 2.46$ per molecule of the cation-exchanger. Based on the literature data $[19,20]$ the structural water molecules may play an important rule as exchange sites.

The solubility experiments showed that the composite and inorganic ion exchangers have good chemical stability (Table 1). As the results indicated that the materials were resistant to $6 \mathrm{M} \mathrm{HNO}_{3}$ and $6 \mathrm{M} \mathrm{HCl}$. The solubility in the $\mathrm{HNO}_{3}$ is higher than in the $\mathrm{HCl}$ and very feeble dissolution was observed in the alkaline medium. There is no chemical dissolution in DMW. It was observed that the chemical solubility of composite is slightly increased 
Table 1. Chemical solubilty of TiW and PATiW in various solvent.

\begin{tabular}{ccccc}
\hline & \multicolumn{4}{c}{ Amount dissolved (mg/L) } \\
\cline { 2 - 5 } Concentrations of \\
Solvent used (50 ml) & \multicolumn{2}{c}{$\mathrm{HCl}$} & \multicolumn{2}{c}{$\mathrm{HNO}_{3}$} \\
\cline { 2 - 5 } & $\mathrm{TiW}$ & $\mathrm{PATiW}$ & $\mathrm{TiW}$ & PATiW \\
\hline $0.1 \mathrm{M} \mathrm{HCl}$ & 4.0 & 6.0 & 12.0 & 20.0 \\
$0.5 \mathrm{M} \mathrm{HCl}$ & 10.0 & 16.0 & 18.0 & 24.0 \\
$1 \mathrm{M} \mathrm{HCl}$ & 24.0 & 34.0 & 30.0 & 38.0 \\
$2 \mathrm{M} \mathrm{HCl}$ & 30.0 & 38.0 & 40.0 & 46.0 \\
$3 \mathrm{M} \mathrm{HCl}$ & 40.0 & 44.0 & 62.0 & 96.0 \\
$4 \mathrm{M} \mathrm{HCl}$ & 56.0 & 82.0 & 86.0 & 114.0 \\
$5 \mathrm{M} \mathrm{HCl}$ & 72.0 & 94.0 & 102.0 & 124.0 \\
$6 \mathrm{M} \mathrm{HCl}$ & 80.0 & 98.0 & 118.0 & 140 \\
water & 0.00 & 0.00 & - & - \\
$0.1 \mathrm{M} \mathrm{NaOH}$ & 0.2 & 0.4 & - & - \\
$1 \mathrm{M} \mathrm{NaOH}$ & 6.0 & 10.0 & - & - \\
\hline
\end{tabular}

than the inorganic material, due to the presence of polyaniline which can dissolute into the solution [16]. Despite this increased in chemical solubility of PATiW than TiW but the mechanical and granular properties of PATiW are higher than TiW [19].

The $\mathrm{pH}$-titration curve of the PATiW shows only one inflexion point indicating that the PATiW behaves as monofunctional. The $\mathrm{pH}$-titration curve (Figure 1) showed slow increase when $\mathrm{NaOH}$ was added $0.30-1.00 \mathrm{mmol}$ and rabid increase when $\mathrm{NaOH}$ added $1.00-1.95$ mmol. This composite exchanger may be a strong acid cationexchanger because the $\mathrm{pH}$-titration curve usually showed a step edge at $1.95 \mathrm{mmol} \cdot \mathrm{g}^{-1}$. This means that the $\mathrm{H}^{+}$ions on the hybrid cation-exchanger were depleted and replaced with $\mathrm{Na}^{+}$ions at that point and the number of $\mathrm{H}^{+}$ sites were equivalent to the same amount of $\mathrm{NaOH}$, i.e. the strong acidic groups $\left(\mathrm{H}^{+}\right)$of the composite cationexchanger are completely converted to the $\mathrm{Na}^{+}$form [16] Thus, theoretical ion-exchange capacity of this hybrid cation-exchanger may be considered as $1.95 \mathrm{mmol} \cdot \mathrm{g}^{-1}$. After that point, in the region when more $\mathrm{NaOH}$ added, the equilibrium $\mathrm{pH}$ further increases but more slowly. This slow increase of pH-titration curve after 1.95 $\mathrm{mmol} \cdot \mathrm{g}^{-1}$ implies due to surface precipitation other than conventional ion exchange or surface adsorption.

The ability of PATiW composite for exchange of cesium is significantly affected by the composition ratio of TiW. The preparation of PATiW with ratio (1:1:1) of poly aniline:titanium:tungstate give the percent absorption $(99 \%, 2.6 \%, 2.6 \%)$ for $\mathrm{Cs}^{+}, \mathrm{Co}^{2+}$ and $\mathrm{Eu}^{3+}$ respectively at $10^{-4} \mathrm{M}$ where, The preparation of PATiW with

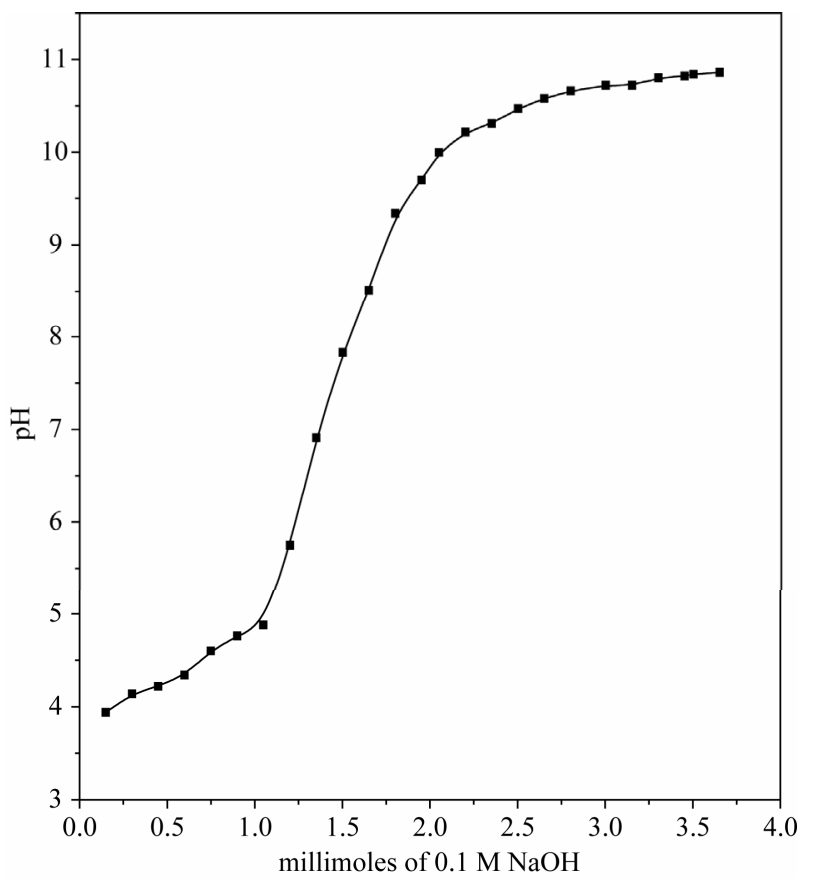

Figure 1. The pH-titration curve of PATiW with $0.1 \mathrm{M}$ $\mathrm{NaOH}$.

ratio (2:1:1) of polyaniline:titanate:tungstate give the percent sorption $(78 \%, 7 \%, 17 \%)$ for $\mathrm{Cs}^{+}, \mathrm{Co}^{2+}$ and $\mathrm{Eu}^{3+}$ respectively this means that the selectivity is decreased than the first ratio, this characterization is showing as in Table 2.

Also the characterization and ability of PATiW for sorption of cesium ions is significantly affected by the concentration of the composition of TiW where by preparing PATiW by adding polyaniline to $0.1 \mathrm{M}$ for each of titanate and tungastate, the results of the product is not selectivity for cesium and soluble in dilute acids.

However, TiW exhibited high granulometric and mechanical properties, showing a good reproducible behavior as is evident from the fact that these materials obtained from various batches did not show any appreciable deviation in their ion-exchange capacities.

Figure 2 shows the ion exchange capacity of PATiW for $\mathrm{Cs}^{+}$as a function of $\mathrm{pH}$. It was found that the capacity increase by increasing the $\mathrm{pH}$ value. This is may be attributed to, with increasing the $\mathrm{pH}$ of the solution the $[\mathrm{H}]^{+}$in solution is decrease which facilitate the released of $\mathrm{H}^{+}$from the exchanger to solution. So the \% uptake values were increased and thus the capacity was increased [16].

Titanium tungstate was found to be high stable, but have poor capacity for metal ions [21]. In this work, an attempt to obtain materials with improved ion exchange properties and have high efficiency for the treatment of nuclear waste. So, PATiW has been synthesized to represent this advanced class of inorganic ion-exchanger, 
Table 2. Factors affecting on preparation of PATiW.

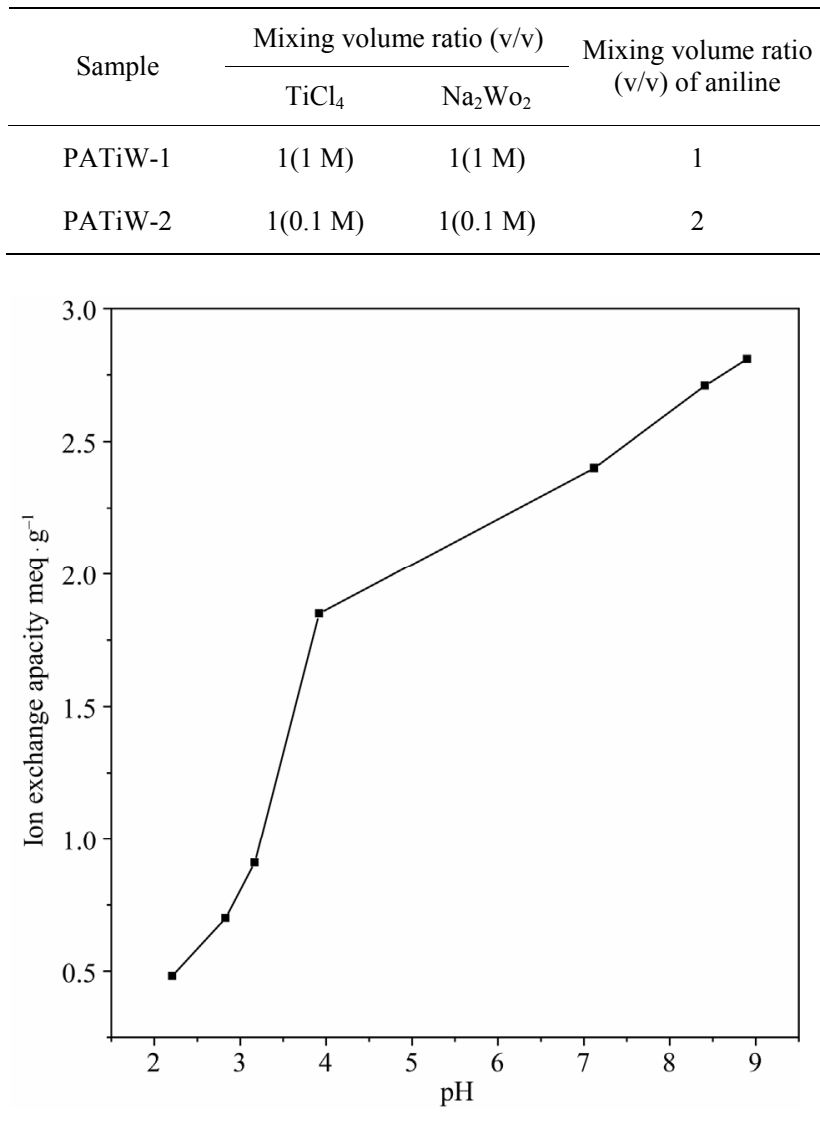

Figure 2. Plots of capacity against $\mathrm{pH}$ for exchange of $\mathrm{Cs}^{+}$ on PATiW at $0.1 \mathrm{M}$ and $25^{\circ} \mathrm{C} \pm 1^{\circ} \mathrm{C}$.

which provided high selective and separation performance for cesium ions of nuclear waste. It was also noticed that the $\mathrm{Cs}^{+}$ion-exchange capacity of the composite material PATiW (1.82 meq. $\left.\mathrm{g}^{-1}\right)$ is higher as compared to inorganic ion-exchanger TiW $\left(0.6 \mathrm{meq} \cdot \mathrm{g}^{-1}\right)$ [22], magneso-silicate $\left(0.57 \mathrm{meq} \cdot \mathrm{g}^{-1}\right)$ and magnesium aluminosilicate $\left(0.77 \mathrm{meq} \cdot \mathrm{g}^{-1}\right)$ [23]. Also it higher than the saturation capacity $\left(\mathrm{meq} \cdot \mathrm{g}^{-1}\right)$ which decrease in the order; $\mathrm{Gd}^{3+}$ $(1.63)>\mathrm{Eu}^{3+}(1.41)>\mathrm{Ce}^{3+}$ (1.34) meq.g ${ }^{-1}$ on titanium (IV) antimonite [24]. The obtained ion-exchange capacity of $\mathrm{Cs}^{+}$on PATiW is higher than the ion-exchange capacity of $\mathrm{Cs}^{+}$on lithium zirconium silicate [25]. The obtained ion-exchange capacity of $\mathrm{Cs}^{+}$on PATiW is higher than the ion-exchange capacity of $\mathrm{Cs}^{+}$on lithium zirconium silicate [24]. The ion exchange capacity on PATiW is higher than that for $\mathrm{Cs}^{+}$on magnesium and cerium titano-antimonates in aqueous $\left(0.7 \mathrm{meq} \cdot \mathrm{g}^{-1}\right)$, in $25 \%$ methnol $\left(0.74 \mathrm{meq} \cdot \mathrm{g}^{-1}\right)$ and in $25 \%$ ethanol $\left(0.8 \mathrm{meq} \cdot \mathrm{g}^{-1}\right)$ [25].

The mechanism of the exchange of $\mathrm{Cs}^{+}$with PATiW can be considered as the following scheme:

$$
\underset{\text { Exchanger phase }}{\mathrm{R}-\mathrm{H}^{+}}+\underset{\text { Solution phase }}{\mathrm{Cs}^{+}} \rightleftharpoons \underset{\text { Exchanger phase }}{\mathrm{R}-\mathrm{Cs}}+\underset{\text { Solution phase }}{\mathrm{H}^{+}}
$$

\begin{tabular}{ccccc}
\multirow{2}{*}{ Aniline } & \multirow{2}{*}{ Appearance after drying } & \multicolumn{3}{c}{ Percent Sorption } \\
\cline { 3 - 5 } & & $\mathrm{Cs}^{+}$ & $\mathrm{Co}^{2+}$ & $\mathrm{Eu}^{3+}$ \\
\hline 10 & Black shiny granules & 99 & 2.6 & 2.6 \\
10 & Black shiny granules & 78 & 7 & 17 \\
\hline
\end{tabular}
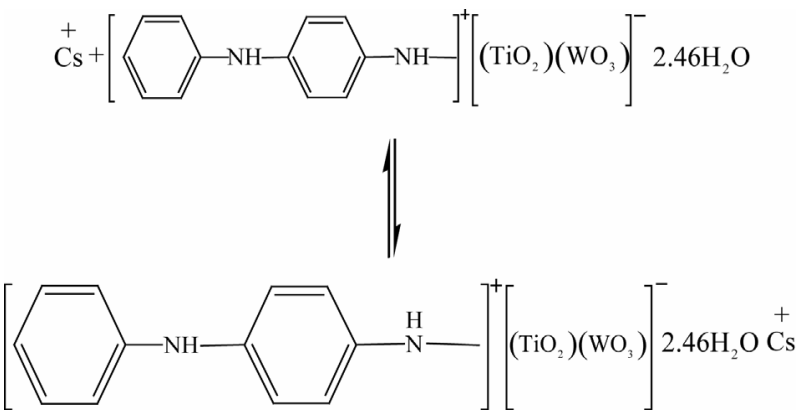

where the negative charge of groups is compensated by $\mathrm{Cs}^{+}$. Possible associations between $\mathrm{Cs}^{+}$and amine groups are indicated by dash-lines ovals.

Characterization of PATiWare described in details using IR, XRD spectrum and TGA-DTA analysis [26].

The distribution coefficient is often a proper quantity to express the distribution of an ion between the exchanger and the solution phase. This is especially true when the exchanging ion is present in the trace concentration, since the ionic composition does not practically change at macro levels in trace ion exchange. So the $K_{d}$ values of $\mathrm{Cs}^{+}$were determined by shaking $40 \mathrm{mg}$ of PATiW sample with $20 \mathrm{~mL}$ of $\mathrm{HNO}_{3}$ solutions containing $10^{-4} \mathrm{~mol} \cdot \mathrm{L}^{-1}$ cesium ion to give different $\mathrm{pH}$ at different reaction temperatures $\left(25^{\circ} \mathrm{C}, 45^{\circ} \mathrm{C}\right.$ and $\left.60^{\circ} \mathrm{C} \pm 1^{\circ} \mathrm{C}\right)$.

The $\log K_{d}$ for $\mathrm{Cs}^{+}$on PATiW were determined at $25^{\circ} \mathrm{C}, 45^{\circ} \mathrm{C}$ and $60^{\circ} \mathrm{C} \pm 1{ }^{\circ} \mathrm{C}$ as afunction of $\mathrm{pH}$ using different concentrations of $\mathrm{HNO}_{3}$ as shown in Figure 3 . The preliminary studies indicated that, the time of equilibrium for the exchange of $\mathrm{Cs}^{+}$with $\mathrm{H}^{+}$form PATiW was attained within $24 \mathrm{~h}$ (sufficient to attain the equilibrium). From the results shown in Figure 3, it can be found that the distribution coefficients for $\mathrm{Cs}^{+}$on PATiW was increased with increasing the $\mathrm{pH}$ of solutions, this trend is an obvious phenomenon and was observed [24,25]. A linear relationship with a slope smaller than the valences of the $\mathrm{Cs}^{+}$was obtained. Analysis the data shown in Figure 3 indicated that the ion exchange reaction deviated from the ideal process. In addition, it was found that the $K_{d}$ values increased with increasing the temperature. The non-ideality may due to a different mechanism such as physical adsorption, chemical reaction or other effects, which takes place besides the ion exchange process $[16,27]$.

The work was directed towards the PATiW as a more 


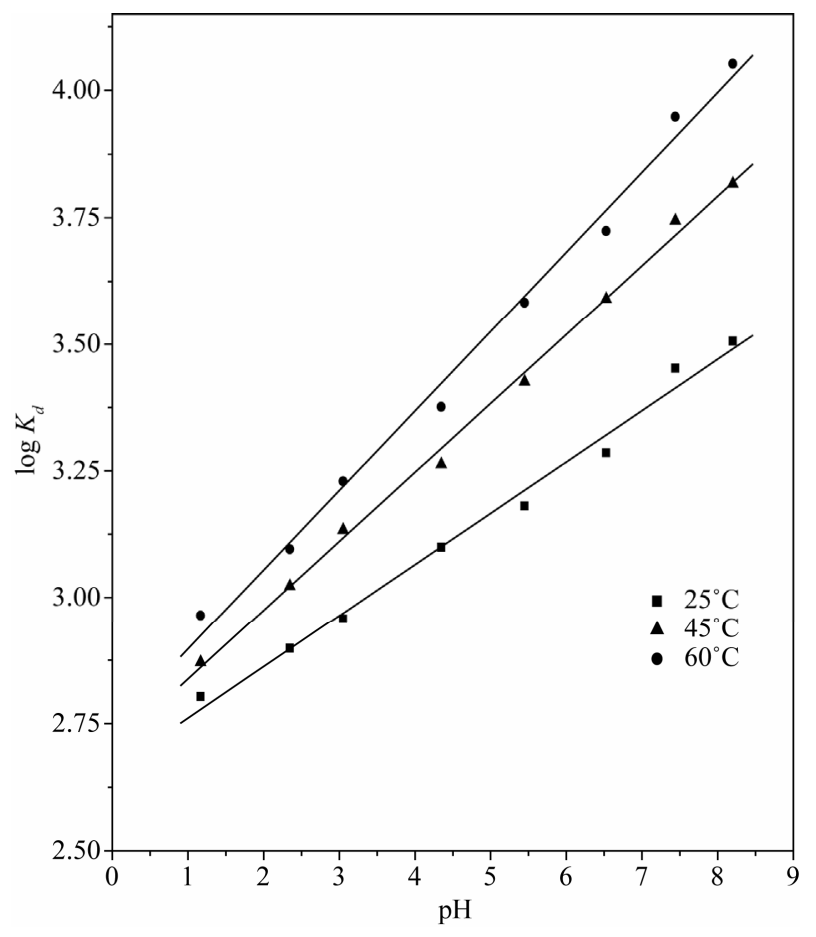

Figure 3. Plots of $\log K_{d}$ against pH for exchange of $\mathrm{Cs}^{+}$on PATiW at different reaction temperatures.

efficient exchange material for $\mathrm{Cs}^{+}$separation. In order to find out the potentiality of the composite cation exchanger in the separation of metal ions, distribution studies for 10 metal ions were performed at different $\mathrm{pH}$ and the values obtained for distribution coefficients are given in Table 3. The distribution coefficients $\left(K_{d}\right)$ for different metal ions $\left(\mathrm{Cs}^{+}, \mathrm{Va}^{5+}, \mathrm{Cr}^{3+}, \mathrm{Zr}^{4+}, \mathrm{As}^{5+}, \mathrm{Mo}^{6+}, \mathrm{Co}^{2+}, \mathrm{Zn}^{2+}\right.$, $\mathrm{Cu}^{2+}$ and $\left.\mathrm{Cd}^{2+}\right)$ on PATiW were determined by batch method as a function of $\mathrm{pH}$. In this metal ions the $K_{d}$ values were determined by shaking $50 \mathrm{mg}$ of PATiW with $5 \mathrm{~mL}$ of $\mathrm{HNO}_{3}$ solutions containing $10^{-5} \mathrm{~mol} \cdot \mathrm{L}^{-1}$ metal ions.

The distribution studies showed that the PATiW was found to be the highly selective for cesium while the other metal ions $\left(\mathrm{Va}^{5+}, \mathrm{Cr}^{3+}, \mathrm{Zr}^{4+}, \mathrm{As}^{5+}, \mathrm{Mo}^{6+}, \mathrm{Co}^{2+}, \mathrm{Zn}^{2+}\right.$, $\mathrm{Cu}^{2+}$ and $\mathrm{Cd}^{2+}$ ) were poorly sorbed on PATiW as in Figure 4. The high uptake of $\mathrm{Cs}^{+}$demonstrates not only the ion-exchange properties but also the adsorption and ionsieve characteristics of the cation-exchanger.

The effect of the size and charge of the exchanging ions on $K_{d}$ values was also observed on PATiW. The $K_{d}$ values show a decreasing trend in this order $\mathrm{Cs}^{+} \gg>>\mathrm{Zr}^{4+}$ $>\mathrm{Mo}^{6+}>\mathrm{Va}^{5+}>\mathrm{As}^{3+}>\mathrm{Cr}^{3+}>\mathrm{Co}^{2+}>\mathrm{Cu}^{2+}>\mathrm{Zn}^{2+}>\mathrm{Cd}^{2+}$ as in Figure 4.

This sequence is in accordance with the unhydrated radii of the exchanging ions. Ions with the smaller unhydrated radii easily enter the pores of the exchanger, which results in higher adsorption [16]. According to [28] the attraction between cations and anions in ionic crystals obey Coulomb's law on the demands for ions of equal charge, a small ion will be attracted either to a greater force or held more tightly than a larger ion as in Table 3.

Therefore, the $K_{d}$ value should increase with decreasing unhydrated radii and increase with electricpotential. On the basis of distribution studies, the most promising property of the material was found to be the high selectivity towards $\mathrm{Cs}^{+}$, which is a major polluting metal in the fission products in radioactive wastes and thus is due to the spacing of the lattice is believed to correspond very closely to the ionic radius of unhydrated $\mathrm{Cs}^{+}$[28] and, thus, is responsible for its selectivity. The selectivity order; $\mathrm{Cs}^{+}>\mathrm{Eu}^{3+}>\mathrm{Co}^{2+}$ onto phosphoric acid activated silico-antimonate, the unhydrated ionic radius was regarded to play a major role affecting on many of these selectivity behavior [29]. The same behavior sequence is similar on resorcinol-formaldehyde (R-F) and zirconylmolybdopyrophosphate (ZMPP) [30], where the selectivity order on R-F and ZMPP samples is $\mathrm{Cs}^{+}>\mathrm{Co}^{2+}>$ $\mathrm{Eu}^{3+}>\mathrm{Zn}^{2+}$.

The distribution coefficient for $\mathrm{Cs}^{+}$is 14,000 at $\mathrm{pH} 8.5$ on PATiW is greater than the values of $K_{d}$ for $\mathrm{Cs}^{+}$on stannic molybdophosphate ion exchanger at the same $\mathrm{pH}$ [31] and on zirconium vanadate at the same $\mathrm{pH}$ [32]. The $K_{d}$ values for $\mathrm{Co}^{2+}$ and $\mathrm{Zn}^{2+}$ on PATiW are lower than the $K_{d}$ values for $\mathrm{Co}^{2+}$ and $\mathrm{Zn}^{2+}$ on Polyaniline $\mathrm{Sn}(\mathrm{IV})$ arsenophosphate and Nylon-6,6, Zr(IV) phosphate [33]. On the reverse of that, the $K_{d}$ values for $\mathrm{Cd}^{2+}$ on PATiW are lower than the $K_{d}$ values for $\mathrm{Cd}^{2+}$ on polyaniline Ce(IV) molybdate [34]. The $K_{d}$ values for $\mathrm{Cu}^{2+}$ on PATiW are lower than the $K_{d}$ values for $\mathrm{Cu}^{2+}$ on acrylamide stannic silicomolybdate [35].

Return to the previous results, regarding that, the studied systems offer very good selectivity for cesium ion. The separation capability of the material has been demonstrated by achieving some important binary separations such as Cs-Co, Cs-Zn, Cs-Cd, Cs-Cu, Cs-Cr, Cs-AS, $\mathrm{Cs}-\mathrm{Zr}, \mathrm{Cs}-\mathrm{V}$, and Cs-Mo as in Table 3.

In order to evaluate the maximum metal sorption capacity of PATiW, the sorbent was contacted with varying concentrations of $\mathrm{Cs}^{+}\left(13-13,290 \mathrm{mg} \cdot \mathrm{g}^{-1}\right)$ until equilibrium was reached. $\mathrm{Cs}^{+}$removing on PATiW was increase with increasing ion concentration in solution until it reached the maximum capacity of PATiW at different reaction temperatures. Equations often used to describe the experimental isotherm data are those developed by Freundlich [36] and by Langmuir [37].

The empirical model of Freundlich equation can be applied to non-ideal sorption on heterogeneous surfaces as well as multilayer sorption and is expresses by the following equation:

$$
q_{e}=K_{f} C_{e}^{1 / n}
$$

where $q_{e}$ is the amount of metal ions sorbed per unit 


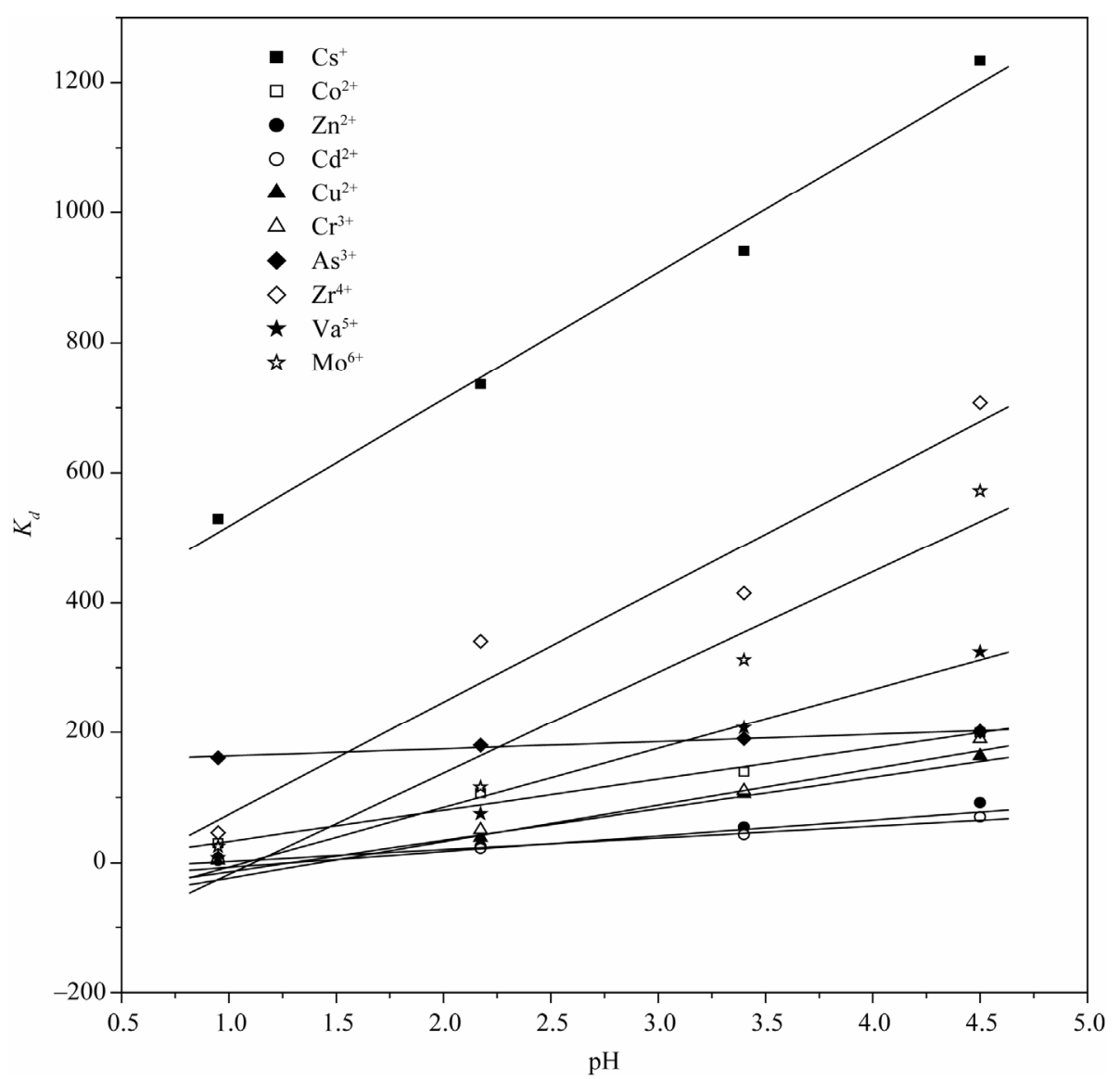

Figure 4. Plots of $K_{d}$ against $\mathrm{pH}$ for exchange of $\mathrm{Cs}^{+}, \mathrm{Co}^{2+}, \mathrm{Zn}^{2+}, \mathrm{Cd}^{2+}, \mathrm{Cu}^{2+}, \mathrm{Cr}^{3+}, \mathrm{As}^{5+}, \mathrm{Zr}^{4+}, \mathrm{Va}^{5+}$ and $\mathrm{Mo}^{6+}$ at $25^{\circ} \mathrm{C} \pm 1^{\circ} \mathrm{C}$ on $\mathrm{PATiW}$ at $10^{-4} \mathrm{M}$ of $\mathrm{Cs}^{+}$and $10^{-5} \mathrm{M}$ for other ions.

Table 3. $K_{d}$ values of $\mathrm{Cs}^{+}, \mathrm{Co}^{2+}, \mathrm{Zn}^{2+}, \mathrm{Cd}^{2+}, \mathrm{Cu}^{2+}, \mathrm{Cr}^{3+}, \mathrm{As}^{5+}, \mathrm{Zr}^{4+}, \mathrm{Va}^{5+}, \mathrm{Mo}^{6+}$ and separation factors $\left(\alpha_{B}^{\mathrm{Cs}^{+}}\right)$of $\mathrm{Cs}^{+}$from other metal ions at different concentrations of $\mathrm{HNO}_{3}$ on $\mathrm{PATiW} 25^{\circ} \mathrm{C} \pm 1^{\circ} \mathrm{C}$.

\begin{tabular}{cccccccccccc}
\hline \multirow{2}{*}{$\begin{array}{c}\text { Metal ions } \\
\mathrm{HNO}_{3}, \mathrm{M}\end{array}$} & \multirow{2}{*}{$\mathrm{Cs}^{+}$} & $\mathrm{Co}^{2+}$ & $\mathrm{Zn}^{2+}$ & $\mathrm{Cd}^{2+}$ & $\mathrm{Cu}^{2+}$ & $\mathrm{Cr}^{3+}$ & $\mathrm{As}^{5+}$ & $\mathrm{Zr}^{4+}$ & $\mathrm{V}^{5+}$ & $\mathrm{Mo}^{6+}$ \\
\hline \multirow{2}{*}{ Water } & \multirow{2}{*}{1256.2} & 199.4 & 91.9 & 69.9 & 163.5 & 199.4 & 201.2 & 733 & 324.1 & 572 \\
& & 6.3 & 13.6 & 17.97 & 7.68 & 6.3 & 6.2 & 1.7 & 3.87 & 2.2 \\
$10^{-3} \mathrm{M}$ & \multirow{2}{*}{907.65} & 119.6 & 35.7 & 42.3 & 105.3 & 91.5 & 190.5 & 415 & 207 & 312 \\
& & 7.5 & 25.4 & 21.45 & 8.6 & 9.9 & 4.76 & 2.18 & 4.38 & 2.9 \\
$10^{-2} \mathrm{M}$ & \multirow{2}{*}{750.31} & 139.8 & 10.5 & 15.9 & 11.5 & 7.1 & 184.9 & 340.5 & 74.8 & 115.5 \\
& & 5.4 & 71.4 & 47.18 & 65.24 & 105.7 & 4.05 & 2.2 & 10.0 & 6.5 \\
$10^{-1} \mathrm{M}$ & \multirow{2}{*}{661.17} & 11.11 & 3.9 & 7.6 & 3.6 & 4.2 & 157.8 & 46.4 & 7.6 & 19.9 \\
& & 59.51 & 169.5 & 86.99 & 183.7 & 157.4 & 4.2 & 14.24 & 86.9 & 33.22 \\
\hline
\end{tabular}

weight of PATiWin equilibrium $(\mathrm{mg} / \mathrm{g}), C_{e}$ is the equilibrium liquid phase concentration $(\mathrm{mg} / \mathrm{L}), K_{F}$ the Freundlich constant indicative of the relative sorption capacity $(\mathrm{mg} / \mathrm{L})$ and $1 / n$ is the heterogeneity factor indicative of the intensity of the sorption process. A linear form of the Freundlich expression can be obtained by:

$$
\ln q_{e}=\ln K_{f}+\frac{1}{n} \ln C_{e}
$$

The Freundlich constants are empirical constants which depend on several environmental factors. The magnitude of the exponent $1 / n$ gives an indication of the adequacy and capacity of the adsorbent/adsorbate system [38]. In most cases, an exponent between 1 and 10 shows beneficial adsorption. The value of $n$ ranges between 0 and 1, and indicates the degree of non-linearity between solution concentration and adsorption as follows [39]: if the value of $n$ is equal to unity, the adsorption is linear; if the value is below unity, this implies that the adsorption process is chemical; if the value is above unity, adsorp- 
tion is a favorable physical process; the more heterogeneous the surface, the closer $n$ value is to 0 [40].

The fit of data to Freundlich isotherm indicates the heterogeneity of the sorbent surface. The linear plot of $\ln q_{\mathrm{e}}$ versus $\ln C_{e}$ (Figure 5) for polyaniline titanotungstste shows that the adsorption obeys to the Freundlich model.

Figure 5 for PATiW show the sorption of $\mathrm{Cs}^{+}$obey Freundlich isotherm over the entire range of sorption concentration studied. Similar results is found for sorption of $\mathrm{Cs}^{+}$with Freundlich isotherm onto polyacylamide cerium titanate [41]. The numerical values of the constants $n$ and $K_{f}$ are computed from the slope and the intercepts, by means of a linear least square fitting method, and also given in Table 4. It can be seen from these data that the Freundlich intensity constants $(n)$ are greater than unity for PATiW. This has physicochemical significance with reference to the qualitative characteristics of the isotherms, as well as to the interactions between metal ions and both adsorbents. In our case, $n>1$ for $\mathrm{Cs}^{+}$, the PATiW shows an increase tendency for sorption with increasing solid phase concentration. This should be attributed to the fact that with progressive surface coverage of adsorbent, the attractive forces between the metal ions such as Vander Waals forces, increases more rapidly than the repulsiveforces, exemplified by short-range electronic or long range Coulombic dipole repulsion, and consequently, the metal ions manifest a stronger tendency to bind to the adsorbent site [42].

Langmuir sorption isotherm model described the monolayer coverage of the sorption surfaces and assumes that sorption occurs on a structurally homogeneous adsorbent and all the sorption sites are energetically identical.

The Langmuir model is probably the best known and most widely applied sorption isotherm. It may be represented as follows:

$$
\frac{C_{e}}{q_{e}}=\frac{1}{q_{o} b}+\frac{C_{e}}{q_{o}}
$$

where $q_{e}$ is the amount of cesium ions sorbed per unit weight of PATiW $(\mathrm{mg} / \mathrm{g}), C_{e}$ the equilibrium concentration of the cesium ions in the equilibrium solution $(\mathrm{mg} / \mathrm{L})$, $q_{o}$ the maximum adsorption capacity corresponding to complete monolayer coverage on the surface $(\mathrm{mg} / \mathrm{g})$, and $b$ is the Langmuir constant $(\mathrm{L} / \mathrm{mg})$ related to the $\left(b \alpha e^{-\Delta G / R T}\right)$ free energy of adsorption.

The linear plot of $\left(C_{e} / q_{e}\right)$ versus $C_{e}$ give straight lines for $\mathrm{Cs}^{+}$sorbed onto both adsorbent, as presented in Figure 6, confirming that this expression is indeed a reasonable representation of chemisorptions isotherm.

The numerical value of constants $q_{o}$ and $b$ evaluated form the slopes and intercepts of each plot are given in Table 4 . The value of saturation capacity $q_{o}$ corresponds

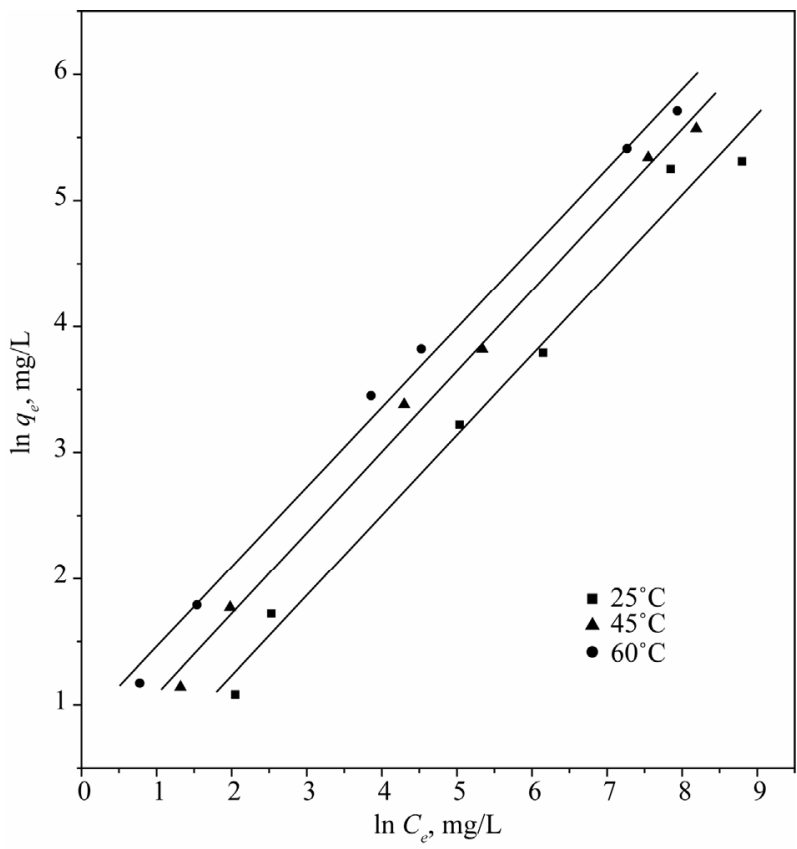

Figure 5. Freundlich isotherm plots for sorption of $\mathrm{Cs}^{+}$onto PATiW at diffrent reaction temperatures.

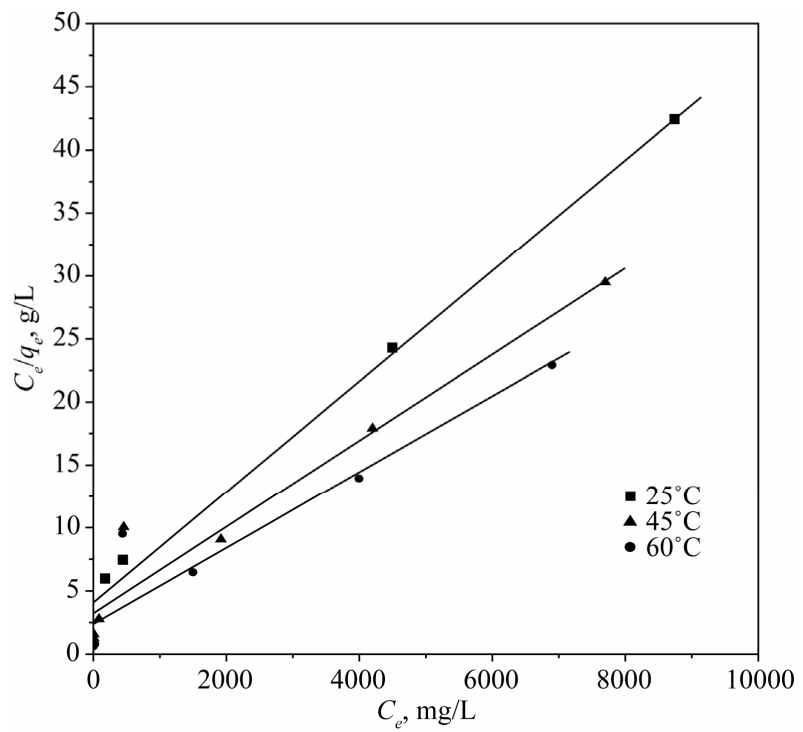

Figure 6. Langmiur isotherm plots for sorption of $\mathrm{Cs}^{+}$onto PATiW at diffrent reaction temperatures.

to the monolayer coverage and defines the total capacity of the adsorbent for a specific metal ion. As it can be seen from Table 4, the monolayer sorption capacity $\left(q_{o}\right)$ values of composite towards $\mathrm{Cs}^{+}$at 2545 and $60 \pm 1$ are $227.79,292.39$ and 332.23 respectively. The Langmuir constants $q_{o}$ and $b$ for $\mathrm{Cs}^{+}$sorbed onto both adsorbent, increased with temperature showing that the sorption capacity and intensity of sorption are enhanced at higher temperatures. This increase in sorption capacity with temperature suggested that the active surface available 
Table 4. Freundlich and Langmuir isotherm parameters for the sorption of $\mathrm{Cs}^{+}$onto PATiW.

\begin{tabular}{cccccccccc}
\hline \multirow{2}{*}{ Adsorbent } & \multirow{2}{*}{ Temperature } & \multicolumn{3}{c}{ Freundlish model parameters } & \multicolumn{5}{c}{ Langmiur model parameters } \\
\cline { 3 - 9 } & & $n$ & $K_{f}(\mathrm{mg} / \mathrm{g})$ & $R^{2}$ & $q_{o}(\mathrm{mg} / \mathrm{g})$ & $b(\mathrm{~L} / \mathrm{mg}) \times 10^{-3}$ & $R^{2}$ & $R_{L}$ \\
\hline \multirow{3}{*}{ PATiW } & $25^{\circ} \mathrm{C}$ & 1.56 & 0.96 & 0.993 & 227.79 & 1.07 & 0.992 & 0.067 \\
& $45^{\circ} \mathrm{C}$ & 1.57 & 1.55 & 0.997 & 292.39 & 1.09 & 0.968 & 0.069 \\
& $60^{\circ} \mathrm{C}$ & 1.58 & 2.29 & 0.997 & 332.23 & 1.26 & 0.953 & 0.058 \\
\hline
\end{tabular}

for sorption has increased with temperature and that adsorption capacity $\left(q_{o}\right)$ increases with the increase in temperature, this indicating that the process was endothermic in nature.

It was observed that the equilibrium adsorption data indicating the favorable Langmuir's sorption isotherms of $\mathrm{Cs}^{+}$onto adsorbent. Conformation of the experimental data into Langmuir isotherm model indicates the homogeneous nature of PATiW as surface, i.e. each $\mathrm{Cs}^{+} /$ PATiW adsorption has equal adsorption activation energy and demonstrates the formation of mono layer coverage of $\mathrm{Cs}^{+}$on the outer surface of PATiW.

One of the essential characteristics of the Langmuir model could be expressed by dimensionless constant called equilibrium parameters $R_{L}$ [43]:

$$
R_{L}=\frac{1}{1+b C_{0}}
$$

where $C_{0}$ is the highest initial concentration of adsorbate $(\mathrm{mg} / \mathrm{L})$ and $b(\mathrm{~L} / \mathrm{mg})$ is Langmuir constant. The parameter $R_{L}$ indicates the nature of shape of the isotherm accordingly: $R_{L}>1$ unfavorable adsorption; $0<R_{L}<1$ favorable adsorption; $R_{L}=0$ irreversible adsorption; $R_{L}=1$ linear adsorption

All the $R_{L}$ values (Table 4) were found to be less than 1 and greater than 0 indicating the favorable sorption isotherms of adsorbent $\mathrm{Cs}^{+}$onto PATiW and the used these adsorbents are optimum for removal of $\mathrm{Cs}^{+}$from waste solutions. The values of $R_{L}$ were determined at different temperatures $25^{\circ} \mathrm{C}, 45^{\circ} \mathrm{C}$ and $60^{\circ} \mathrm{C} \pm 1^{\circ} \mathrm{C}$ over the broad concentration range and the results are shown in Figure 7 for PATiW. All the $R_{L}$ values were found to be less than one and greater than zero indicating the favourable adsorption of $\mathrm{Cs}^{+}$onto PATiW.

The detailed analysis of the $R^{2}$ values showed that the Freundlich model fit the adsorption data better than the Langmuir model at different temperatures. Freundlich sorption isotherm does not predict any saturation of the solid surface thus envisages infinite surface coverage mathematically [44]. Which indicates that $\mathrm{Cs}^{+}$sorbed on PATiW as a monolayer deposition of adsorbate on localized sites followed by a multilayer sorption with interaction between sorbed molecules that having heterogeneous energy distribution, accompanied by interaction be-

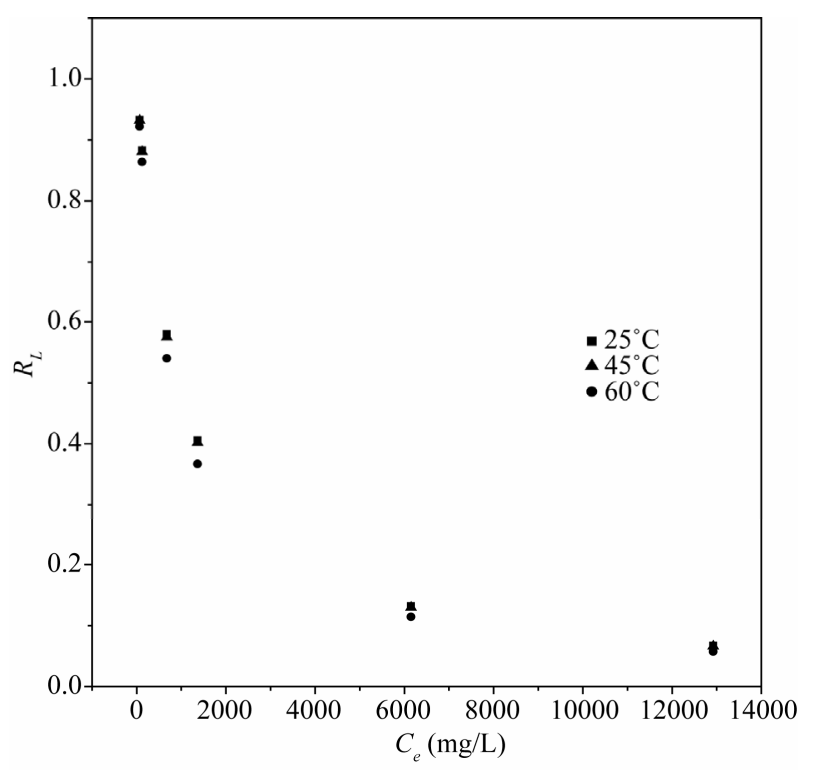

Figure 7. Plots of separation factor, $R_{L}$, against initial concentration, Co, for sorption of $\mathrm{Cs}^{+}$onto PATiW at different reaction temperatures.

tween the adsorbed molecules. The same result was found for physically sorbed of $\mathrm{Cs}^{+}$on magneso-silicate and magnesium aluminosilicate [45]. The theoretical capacity $\left(q_{o}\right)$ of $\mathrm{Cs}^{+}$on PATiW were calculated as 227.8 and $181.8 \mathrm{mg} \cdot \mathrm{g}^{-1}$, respectively, against 205.9 and 156.15 $\mathrm{mg} \cdot \mathrm{g}^{-1}$ found experimentally indicating that this sorption is not completely match with Langmiure isotherm.

Breakthrough curves of PATiW for the conditions stated previously are shown in Figures 8 and 9. Batch experimental data are often difficult to apply directly to the fixed bed sorption column because isotherms are unable to give accurate data for scale up since a flow in the column is not at equilibrium. Fixed bed column sorption experiments were carried out to study the sorption dynamics. The fixed bed column operation allows more efficient utilization of the sorption capacity than the batch process. The shape of the breakthrough curve and the time for the breakthrough appearance are the predominant factors for determining the operation and the dynamic response of the sorption column [16]. The general position of the breakthrough curve along the volume/time axis depends on the capacity of the column 


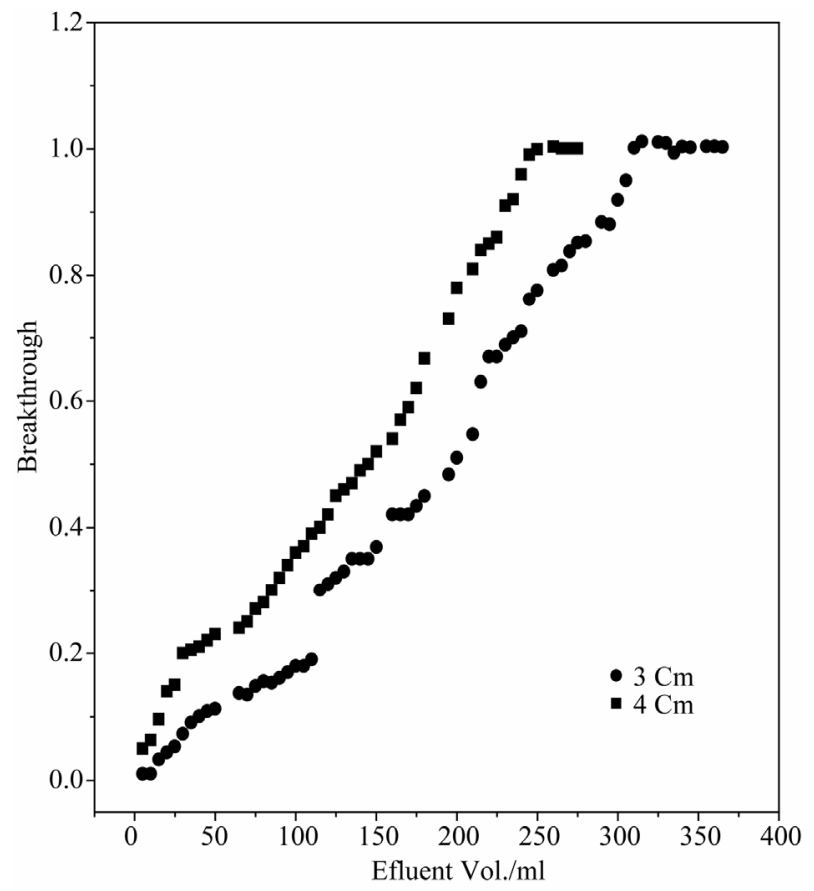

Figure 8. Performance of PATiW column of cesium seperation from neutral solutions at different bed depth, 140 $\mathrm{mg} \cdot \mathrm{L}^{-1}$ and flow rate $2.5 \mathrm{ml} \cdot \mathrm{min}^{-1}$.

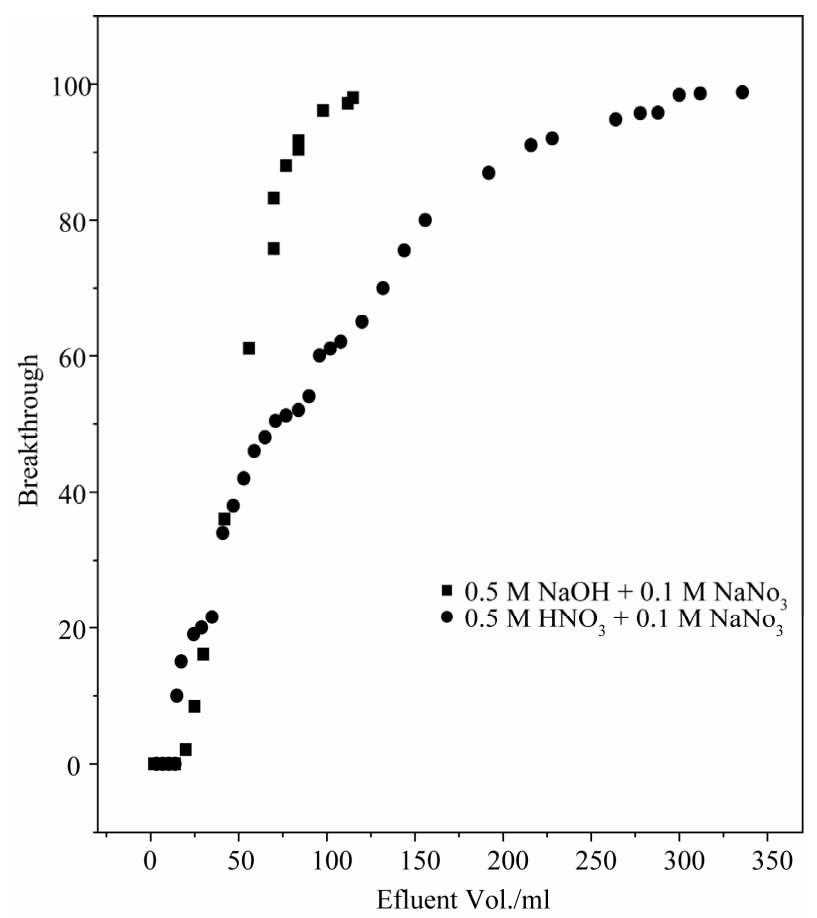

Figure 9. Performance of PATiW column of cesium separation from alkaline and acidic simulant solutions at bed depth $1 \mathrm{~cm}, 13 \mathrm{mg} \cdot \mathrm{L}^{-1}$ and flow rate $0.7 \mathrm{ml} \cdot \mathrm{min}^{-1}$.

with respect to bed height, the feed concentration and flow rate [46].

The breakthrough curves $\left(C / C_{0}\right.$ vs volume) obtained for $\mathrm{Cs}^{+}$sorption onto PATiW at different bed depths (3.0, and $4.0 \mathrm{~cm}$ ) for a constant linear flow rate of $2.5 \mathrm{~mL} / \mathrm{min}$ and at $140 \mathrm{mg} / \mathrm{L}$ of neutral aqueous cesium concentration are shown in Figure 8.

It can be observed a similar behavior in each curve and a tendency to follow an S shape which is characteristic of an ideal sorption. The results indicate that the volume of breakthrough varies with bed depth. The bed capacity and the percent removal (column performance) for $\mathrm{Cs}^{+}$ increased with increasing bed height, as more binding sites were available for sorption. The increase in the ion sorption with bed depth was due to the increase in the sorbent doses in larger beds, which provided greater sorption sites for $\mathrm{Cs}^{+}$. It was found that the break-through capacities for $\mathrm{Cs}^{+}$onto PATiW at different bed depths 3.0 and $4.0 \mathrm{~cm}$ are 5.1 and $6.5 \mathrm{mg} \cdot \mathrm{g}^{-1}$ respectively. Which there are more than the breakthrough capacity $0.67 \mathrm{mg} \cdot \mathrm{g}^{-1}$ for $\mathrm{Cs}^{+}$onto phosphoric acid activated silicoantimonate [47].

The rate determining step can be inferred from a stopflow test, in which the flow is halted and restarted during column loading. The behavior of $\mathrm{C} / \mathrm{C}_{0}$ after the column is restarted provides information about the mass transfer mechanism. If the exchange rate is controlled by diffusion in the particle phase, diffusion of $\mathrm{Cs}^{+}$within the particles continues even after flow is stopped. Highly concentrated cesium on the outer layers of the particles will diffuse toward particle centers, there by leveling the concentration gradient in the particle and reducing the $C / C_{0}$ on the surface. The result is a decrease in $C / C_{0}$ when the column is restarted. As the run continues, the concentration gradients in the particles are reestablished and the breakthrough curve will slowly approach the shape it would have had without interruption [48].

In each of the PATiW column test where flow was interrupted (Figure 8) there was a significant decrease in $C / C_{0}$ when the operation was restarted and it took approximately 50 - 150 bed volumes for the curve shape to be re-established. This phenomenon is indicative of a particle diffusion controlled system. This stop flow test is also analogous to the batch interruption test reported by [49] in which the sorbent particles are removed from the solution for a brief period of time and then re-immersed [16]. The interruption gives time for concentration gradients in the solid phase to level out. Then, when the particles are re-immersed, the exchange rate is temporarily faster. This can be seen as a momentary increase in the fractional attainment of equilibrium in the time following re-immersion.

The breakthrough curves for the separation of cesium from acid solution $\left(0.5 \mathrm{M} \mathrm{HNO}_{3}+0.1 \mathrm{M} \mathrm{NaNO}_{3}\right)$ and from alkaline simulant solution $(0.5 \mathrm{M} \mathrm{NaOH}+0.1 \mathrm{M}$ $\mathrm{NaNO}_{3}$ ) using PATiW columns at bed depth $1 \mathrm{~cm}$, flow rate of $0.7 \mathrm{ml} \cdot \mathrm{min}^{-1}$ and $13 \mathrm{mg} \cdot \mathrm{g}^{-1}$ of cesium chloride 


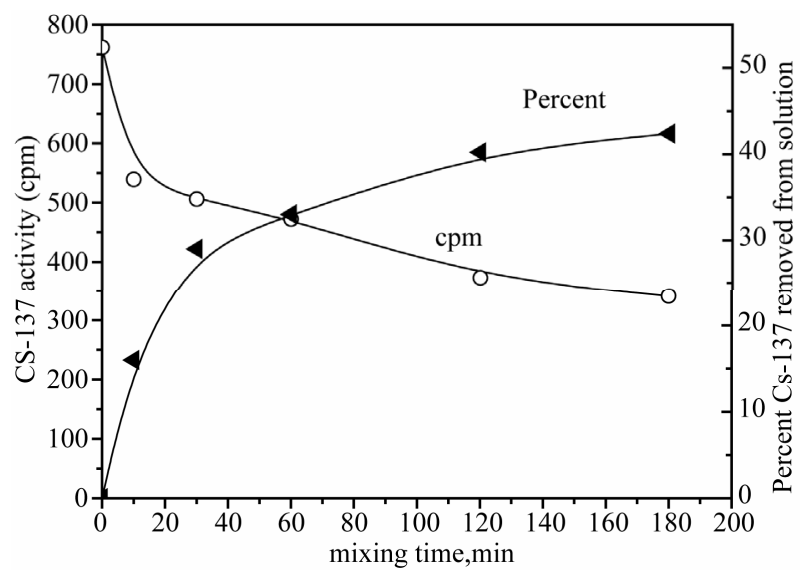

Figure 10. Partitioning of cesium-134 as a function of mixing time.

were represented in Figure 9. In this figure the breakthrough of cesium begins earlier with respect acid stimulant solution (at $22 \mathrm{ml}$ ) than with respect to alkaline solution begin very early (at $10 \mathrm{ml}$ ) and the sorption capacity was found to be 2.32 and $0.66 \mathrm{mg} \cdot \mathrm{g}^{-1}$ for acid and alkaline columns, respectively. This means that PATiW can be applied to remove radiocesium from acidic solutions where most of the inorganic ion exchangers [50,51] such as lithium titanate, tin silicate and titanium-ferrocyanides, exhibit very low ion exchange efficiency in the high acidic media. Where for alkaline solution the breakthrough begins very early with capacity very small.

This system offer very good selectivity for cesium sorption, since if the break-through was studied where the feed solution is a simulated active waste solution containing different elements of various valence states such as $\mathrm{Cs}^{+}, \mathrm{Va}^{5+}, \mathrm{Cr}^{3+}, \mathrm{Zr}^{4+}, \mathrm{As}^{5+}, \mathrm{Mo}^{6+}, \mathrm{Co}^{2+}, \mathrm{Zn}^{2+}$, $\mathrm{Cu}^{2+}$ and $\mathrm{Cd}^{2+}$. So all these elements could be separated in the first few milliliters of the effluent solution while cesium is retained completely on the column beds.

The milk cesium-134 activity was measured over a 3-h period to determine the equilibrium time. Fat separation was not observed except for long mixing time ( $>3 \mathrm{~h}$ ) [52]. The uptake of cesium-134 and the decaying of cesium activity are shown as a function of mixing time in Figure 10. The reaction half-life was $30 \mathrm{~min}$, and by $60 \mathrm{~min}$ the reaction was $80 \%$ complete. The reaction reached at equilibrium at $2 \mathrm{~h}[16]$.

\section{Conclusions}

A cesium selective composite cation exchanger PATiWhaving good ion-exchange capacity (1.8) have been prepared successfully. Cesium ion sorption was fit best to the Freundlich isotherm model. The breakthrough capacity was different with the bed depths and the solution that used. The PATiWcan be used to removal cesium ion from aqueous, high acid solutions and milk.

\section{REFERENCES}

[1] IAEA, "Remediation of Areas Contaminated by Past Activities and Accidents, Safety Requirements," Safety Standards Series No. WSR-3, STI/PUB/1176, IAEA, Vienna, 2003.

[2] P. J. Coughtrey and M. C. Thorne, "Radionuclide Distribution and Transport in Terrestrial and Aquatic Ecosystems," A. A. Balkema, Rotterdam, 1983.

[3] A. Clearfield, "Inorganic Ion Exchange Materials," CRC Press, Boca Raton, 1982.

[4] A. A. Khan and M. M. Alam, "New and Novel OrganicInorganic Type Crystalline 'Polypyrrolel/Polyantimonic Acid' Composite System: Preparation, Characterization and Analytical Applications as a Cation-Exchange Material and $\mathrm{Hg}(\mathrm{II})$ Ion-Selective Membrane Electrode," Analytica Chimica Acta, Vol. 504, 2004, pp. 253-264. doi:10.1016/j.aca.2003.10.054

[5] A. A. Khan, "Inamuddin, Preparation, Physico-Chemical Characterization, Analytical Applications and Electrical Conductivity Measurement Studies of an 'Organic-InorGanic' Composite Cation-Exchanger: Polyaniline Sn(IV) Phosphate," Reactive \& Functional Polymers, Vol. 66, 2006, pp. 1649-1663.

doi:10.1016/j.reactfunctpolym.2006.06.007

[6] A. A. Khan and M. M. Alam, "Determination and Separation of $\mathrm{Pb}^{2+}$ from Aqueous Solutions Using a Fibrous Type Organic-Inorganic Hybrid Cation-Exchange Material: Polypyrrole Thorium(IV) Phosphate," Reactive \& Functional Polymers, Vol. 63, No. 2, 2005, pp. 119-133. doi:10.1016/j.reactfunctpolym.2005.02.001

[7] A. A. Khan and M. M. Alam, "Synthesis, Characterization and Analytical Applications of a New and Novel 'Organic-Inorganic' Composite Material as a Cation Exchanger and $\mathrm{Cd}(\mathrm{II})$ Ion-Selective Membrane Electrode: Polyaniline Sn(IV) Tungstoarsenate," Reactive \& Functional Polymers, Vol. 55, No. 3, 2003, pp. 277-290. doi:10.1016/S1381-5148(03)00018-X

[8] R. Niwas, A. A. Khan and K. G. Varshney, "Synthesis and Ion Exchange Behaviour of Polyaniline Sn(IV) Arsenophosphate: A Polymeric Inorganic Ion Exchanger," Colloids and Surfaces A, Vol. 150, 1999, pp. 7-14. doi:10.1016/S0927-7757(98)00843-7

[9] K. G. Varshney, N. Tayal and U. Gupta, "Acrylonitrile Based Cerium (IV) Phosphate as a New Mercury Selective Fibrous Ion-Exchanger: Synthesis, Characterization and Analytical Applications," Colloids and Surfaces A, Vol. 145, No. 2-3, 1998, pp. 71-81. doi:10.1016/S0927-7757(98)00657-8

[10] G. Alberti, M. Casciola, C. Dionigi and R. Vivani, Proceedings of International Conference on Ion-Exchange, ICIE'95, Takamtsu, 1995.

[11] A. Mardan, R. Ajaz, A. Mehmood and S. M. Raza, "Preparation of Silica Potassium Cobalt Hexacyanoferrate Composite Ion Exchanger and Its Uptake Behavior for Cesium," Separation and Purification Technology, Vol. 16, No. 2, 1999, pp. 147-158. doi:10.1016/S1383-5866(98)00121-X 
[12] Z. Alam and S. A. Nabi, "Synthesis and Characterization of a Thermally Stable Strongly Acidic Cd(II) Ion Selective Composite Cation-Exchanger: Polyaniline Ce(IV) Molybdate," Desalination, Vol. 250, No. 2, 010, pp. 515-522.

[13] Y. A. Ismail, "Synthesis and Characterization of Electrically Conducting Poly-O-Methoxyaniline $\mathrm{Zr}(1 \mathrm{~V})$ Molybdate Cd(II) Selective Composite Cation-Exchanger," Desalination, Vol. 250, No. 2, 2010, pp. 523-529. doi:10.1016/j.desal.2008.06.033

[14] S. A. Nabi, Mu. Naushad and R. Bushra, "Synthesis and Characterization of a New Organic-Inorganic $\mathrm{Pb}^{2+}$ Selective Composite Cation Exchanger Acrylonitrile Stannic(IV) Tungstate and Its Analytical Applications," Chemical Engineering Journal, Vol. 152, No. 1, 2009, pp. 80-87. doi:10.1016/j.cej.2009.03.033

[15] T. P. Valsala, S. C. Roy, J. G. Shah, J. Gabriel, K. Raj and V. Venugopal, "Removal of Radioactive Caesium from Low Level Radioactive Waste (LLW) Streams Using Cobalt Ferrocyanide Impregnated Organic Anion Exchanger," Journal of Hazardous Material, Vol. 166, No. 2-3, 2009, pp. 1148-1153. doi:10.1016/j.jhazmat.2008.12.019

[16] I. M. El-Naggar, E. S. Zakaria, I. M. Ali, M. Khalil and M. F. El-Shahat, "Studies on Synthetic Polyaniline Titanotungstate and Its Applications for Cesium Treatment," Inorganic Chemistry, 2011, in Press.

[17] N. E. Topp and K. W. Pepper, "Properties of Ion Exchange Resin in Relation to Their Structure, I. Titration Curves," Journal of the Chemical Society, Vol. 690, 1949, pp. 3299-3303. doi:10.1039/jr9490003299

[18] M. Qureshi, J. P. Gupta and V. Sharma, "Comparison of the Ion-Exchange Behaviour of Zirconium, Thorium, Vanadium, Uranium, Stannic and Titanium Tungstates," Talanta, Vol. 21, No. 1, 1974, pp. 102-106. doi:10.1016/0039-9140(74)80069-X

[19] A. A. Khan and M. M. Alam, "Synthesis, Characterization and Analytical Applications of a New and Novel 'Organic-Inorganic' Composite Material as a Cation Exchanger and Cd(II) Ion-Selective Membrane Electrode: Polyaniline Sn(IV) Tungstoarsenate," Reactive \& Functional Polymers, Vol. 55, No. 3, 2003, pp. 277-290. doi:10.1016/S1381-5148(03)00018-X

[20] I. M. Ali, "Synthesis and Sorption Behavior of Semicrystalline Sodium Titanate as a New Cation Exchanger," Journal of Radioanalytical and Nuclear Chemistry, Vol. 260, No. 1, 2004, pp. 149-157. doi:10.1023/B:JRNC.0000027074.36548.29

[21] M. Qureshi, J. P. Gupta and V. Sharma, "Comparison of the Ion-Exchange Behaviour of Zirconium, Thorium, Vanadium, Uranium, Stannic and Titanium Tungstates," Talanta, Vol. 21, No. 1, 1974, pp. 102-106. doi:10.1016/0039-9140(74)80069-X

[22] T. Möller, A. Clearfield and R. Harjula, "Preparation of Hydrous Mixed Metal Oxides of Sb, Nb, Si, Ti and $\mathrm{W}$ with a Pyrochlore Structure and Exchange of Radioactive Cesium and Strontium Ions into the Materials," Microporous and Mesoporous Materials, Vol. 54, No. 1, 2002, pp. 187-199. doi:10.1016/S1387-1811(02)00320-7
[23] I. M. El-Naggar and M. M. Abou-Mesalam, "Novel Inorganic Ion Exchange Materials Based on Silicates; Synthesis, Structure and Analytical Applications of MagnesoSilicate and Magnesium Alumino-Silicate Sorbents," Journal of Hazardous Material, Vol. 149, No. 3, 2007, pp. 686-692. doi:10.1016/j.jhazmat.2007.04.029

[24] E. S. Zakaria, I. M. Ali and I. M. El-Naggar, "Thermodynamics and Ion Exchange Equilibria of $\mathrm{Gd}^{3+}, \mathrm{Eu}^{3+}$ and $\mathrm{Ce}^{3+}$ Ions on $\mathrm{H}^{+}$Form of Titanium(IV) Antimonate," Colloids and Surfaces A, Vol. 210, No. 1, 2002, pp. 3340. doi:10.1016/S0927-7757(02)00216-9

[25] E. S. Zakaria, I. M. Ali and H. F. Aly, "Kinetic Aspects and Swelling Changes of Magnesium and Cerium Titano-Antimonates in Aqueous and Mixed Solvents," Journal of Colloid and Interface Science, Vol. 338, No. 2, 2009, pp. 346-352. doi:10.1016/j.jcis.2009.06.031

[26] I. M. El-Naggar, E. S. Zakaria, I. M. Ali, M. Khalil and M. F. El-Shahat, "Kinetic Modeling Analysis for the Removal of Cesium Ions from Aqueous Solutions Using Polyaniline Titanotungstate," Arabian Journal of Chemistry, Vol. 5, No. 1, 2010, pp. 109-119. doi:10.1016/j.arabjc.2010.09.028

[27] I. M. Ali, E. S. Zakaria, M. M. Ibrahim and I. M. El-Naggar, "Synthesis, Structure, Dehydration Transformations and Ion Exchange Characteristics of Iron-Silicate with Various $\mathrm{Si}$ and $\mathrm{Fe}$ Contents as Mixed Oxides," Polyhedron, Vol. 27, No. 1, 2008, pp. 429-439. doi:10.1016/j.poly.2007.09.034

[28] R. G. Dosch, N. E. Brown, H. P. Stephens and R. G. Anthony, Sandia National Laboratories Report, SAND92-2737C, 1992.

[29] I. M. Ali, "Sorption Studies of ${ }^{134} \mathrm{Cs},{ }^{60} \mathrm{Co}$ and ${ }^{152+154} \mathrm{Eu}$ on Phosphoric Acid Activated Silico-Antimonate Crystals in High Acidic Media," Chemical Engineering Journal, Vol. 155, No. 3, 2009, pp. 580-585. doi:10.1016/j.cej.2009.07.050

[30] S. A. Shady, "Selectivity of Cesium from Fission Radionuclides Using Resorcinol-Formaldehyde and Zirconyl-Mo-lybdopyrophosphate as Ion-Exchangers," Journal of Hazardous Material, Vol. 167, 2009, pp. 947-952.

[31] M. G. Marageh, S. W. Husaina and A. R. Khanchi, "The Use of Clinoptilolite and Its Sodium form for Removal of Radioactive Cesium, and Strontium from Nuclear Wastewater and $\mathrm{Pb}^{2+}, \mathrm{Ni}^{2+}, \mathrm{Cd}^{2+}, \mathrm{Ba}^{2+}$ from Municipal Wastewater," Applied Radiation and Isotopes, Vol. 50, No. 4 1999, pp. 655-660. doi:10.1016/S0969-8043(98)00134-1

[32] S. Lahiri, K. Roy, S. Bhattacharya, S. Maji and S. Basu, "Separation of ${ }^{134} \mathrm{Cs}$ and ${ }^{152} \mathrm{Eu}$ Using Inorganic Ion Exchangers, Zirconium Vanadate and Ceric Vanadate," Applied Radiation and Isotopes, Vol. 63, No. 3, 2005, pp. 293-297. doi:10.1016/j.apradiso.2005.03.007

[33] S. A. I. Khan and A. A. Khan, "Synthesis, Characterization and Ion-Exchange Properties of a New and Novel 'Organic-Inorganic' Hybrid Cation-Exchanger: Nylon6,6, Zr(IV) Phosphate,” Talanta, Vol. 71, No. 2, 2007, pp. 841-847. doi:10.1016/j.talanta.2006.05.042

[34] Z. Alam, Inamuddin and S. A. Nabi, "Synthesis and Characterization of a Thermally Stable Strongly Acidic Cd(II) Ion Selective Composite Cation-Exchanger: Poly- 
aniline Ce(IV) Molybdate," Desalination, Vol. 250, No. 2, 2010, pp. 515-522. doi:10.1016/j.desal.2008.09.008

[35] A. M. Khan, S. A. Ganai and S. A. Nabi, "Synthesis of a Crystalline Organic-Inorganic Composite Exchanger, Acrylamide Stannic Silicomolybdate: Binary and Quantitative Separation of Metal Ions," Colloids and Surfaces A, Vol. 337, No. 1-3, 2009, pp. 141-145. doi:10.1016/j.colsurfa.2008.12.012

[36] H. M. F. Freundlich, "Uber Die Adsorption in Losungen, Zeitschrift fur Physikalische Chemie,” Leipzig, Vol. 57A, 1906, pp. 385-470.

[37] I. Langmuir, "The Constitution and Fundamental Properties of Solids and Liquids," Journal of the American Chemical Society, Vol. 38, No. 11, 1916, pp. 2221-2295. doi:10.1021/ja02268a002

[38] M. S. Bilgili, "Adsorption of 4-Chlorophenol from Aqueous Solutions by Xad-4 Resin: Isotherm, Kinetic, and Thermodynamic Analysis," Journal of Hazardous Materials, Vol. 137, No. 1, 2006, pp. 157-164. doi:10.1016/j.jhazmat.2006.01.005

[39] R. E. Treybal, "Mass Transfer Operations," McGraw-Hill, New York, 1987.

[40] B. Al-Duri, "Use of Adsorbents for the Removal of Pollutants from Wastewaters," In: G. McKay, Ed., CRC Press, 1996, p. 133.

[41] I. M. El-Naggar, G. M. Ibrahima, E. A. El-Kadya and E. A. Hegazyb, "Sorption Mechanism of $\mathrm{Cs}^{+}, \mathrm{Co}^{2+}$ and $\mathrm{Eu}^{3+}$ ions onto EGIB Sorbent," Desalination, Vol. 237, No. 1, 2009, pp. 147-154. doi:10.1016/j.desal.2007.11.057

[42] D. Mohan and K. P. Singh, "Single- and Multi-Component Adsorption of Cadmium and Zinc Using Activated Carbon Derived from Bagasse-An Agricultural Waste," Water Research, Vol. 36, No. 9, 2002, pp. 2304-2318. doi:10.1016/S0043-1354(01)00447-X

[43] D. Mohan and S. Chander, "Single, Binary, and Multicomponent Sorption of Iron and Manganese on Lignite," Journal of Colloid and Interface Science, Vol. 299, No. 1, 2006, pp. 76-87. doi:10.1016/j.jcis.2006.02.010

[44] S. M. Hasany, M. M. Saeed and M. Ahmed, "Sorption and Thermodynamic Behavior of Zinc(II)-Thiocyanate Complexes onto Polyurethane Foam from Acidic Solutions," Journal of Radioanalytical and Nuclear Chemistry,
Vol. 252, No. 3, 2002, pp. 477-484. doi:10.1023/A:1015890317697

[45] I. M. El-Naggar and M. M. Abou-Mesalam, "Novel Inorganic Ion Exchange Materials Based on Silicates; Synthesis, Structure and Analytical Applications of MagnesoSilicate and Magnesium Alumino-Silicate Sorbents," Journal of Hazardous Material, Vol. 149, No. 3, 2007, pp. 686-692. doi:10.1016/i.jhazmat.2007.04.029

[46] S. Netpradit, P. Thiravetyan and S. Towprayoon, "Evaluation of Metal Hydroxide Sludge for Reactive Dye Adsorption in a Fixed-Bed Column System," Water Research, Vol. 38, No. 1, 2004, pp. 71-78. doi:10.1016/j.watres.2003.09.007

[47] I. M. Ali, "Sorption Studies of ${ }^{134} \mathrm{Cs},{ }^{60} \mathrm{Co}$ and ${ }^{152+154} \mathrm{Eu}$ on Phosphoric Acid Activated Silico-Antimonate Crystals in High Acidic Media," Chemical Engineering Journal, Vol. 155, No. 3, 2009, pp. 580-585. doi:10.1016/j.cej.2009.07.050

[48] T. J. Trantera, R. S. Herbsta, T. A. Todda, A. L. Olsona and H. B. Eldredge, "Evaluation of Ammonium Molybdophosphate-Polyacrylonitrile (AMP-PAN) as a Cesium Selective Sorbent for the Removal of ${ }^{137}$ Cs from Acidic Nuclear Waste Solutions," Advances in Environmental Research, Vol. 6, No. 2, 2002, pp. 107-121. doi:10.1016/S1093-0191(00)00073-3

[49] F. Helfferich, "Ion Exchange," McGraw-Hill, New York, 1962.

[50] I. M. El-Naggar, E. I. Shabana and M. I. El-Dessouky, "Ion Exchange Behaviour of Hydrous Tin Oxide: Kinetics of Anion Exchange," Talanta, Vol. 39, No. 6, 1992, pp. 653-657. doi:10.1016/0039-9140(92)80076-P

[51] E. S. Zakaria, I. M. Ali and H. F. Aly, "Kinetic Study of the Isotopic Exchange of $\mathrm{Na}^{+}$and $\mathrm{Zn}^{2+}$ Ions on Iron and Chromium Titanates," Journal of Radioanalytical and Nuclear Chemistry, Vol. 260, No. 2, 2004, pp. 389-397. doi:10.1023/B:JRNC.0000027114.32878.d2

[52] M. D. Kaminski, L. Nunez, M. Pourfarzaneh and C. Negri, "Cesium Separation from Contaminated Milk Using Magnetic Particles Containing Crystalline Silicotitanates," Separation and Purification Technology, Vol. 21, No. 1-2, 2000, pp. 1-8. doi:10.1016/S1383-5866(99)00062-3 